\title{
Internationalisation and firm performance of emerging market firms: exploring the moderating effects of differential knowledge-based resources
}

\author{
Shufeng Xiao \\ HUFS Business School, \\ Hankuk University of Foreign Studies, \\ 270, Imun-dong, Dongdaemun-gu, \\ Seoul, 130-791, South Korea \\ Fax: +82-2-2173-3558 \\ Email: bizsxiao@hufs.ac.kr
}

\begin{abstract}
Building on the knowledge-based view (KBV) of the firm, this study updates and extends research on the internationalisation-performance relationship in emerging market firms by examining the moderating impacts of two types of knowledge-based resources. Empirical results obtained from a large longitudinal sample of manufacturing firms in China show that not all knowledge is equally important for emerging market firms to succeed in the process of international expansion. More specifically, technological knowledge is shown to have a significant positive influence on the relationship between internationalisation and performance of emerging market firms, whereas the effect of marketing knowledge does not appear in the regression models. An appropriate explanation for this finding is that internationalising emerging market firms may find it more difficult to replicate and transfer their marketing knowledge or know-how than technological knowledge in different foreign environment settings because marketing knowledge is more context dependent than technological knowledge. This study brings together the study of knowledge characteristics and emerging market firms' international expansion, which not only advances our understanding of how emerging market firms can succeed in the process of international expansion, but also provides important implications and avenues for future research.
\end{abstract}

Keywords: international expansion; emerging market firms; knowledge-based view; KBV.

Reference to this paper should be made as follows: Xiao, S. (2017) 'Internationalisation and firm performance of emerging market firms: exploring the moderating effects of differential knowledge-based resources', Int. J. Multinational Corporation Strategy, Vol. 2, No. 1, pp.26-50.

Biographical notes: Shufeng (Simon) Xiao is an Associate Professor of International Business at the HUFS Business School, Hankuk University of Foreign Studies (HUFS), Seoul, South Korea. He received his $\mathrm{PhD}$ in International Business from the Korea University Business School. His research interests centre on emerging multinational enterprises, institutional theory in strategic management, cross-cultural management, and foreign subsidiary management in emerging markets, with a particular focus on China. His research has appeared in the Journal of International Management, Management International Review, International Business Review, Thunderbird International Business Review, International Journal of Human Resource Management, among others. 


\section{Introduction}

As an extension of the resource-based view, the knowledge-based view (KBV) of the firm has been a pivotal theoretical lens to understand organisational phenomena in strategic management and international business strategy. The core idea behind the KBV is that knowledge is the most strategically important firm resource, and the more valuable and rare intangible knowledge plays the central role in developing sustainable competitive advantage and creating strategic opportunities that represent new potential sources of revenue (Grant, 1996; Kogut and Zander, 1992; Zahra and George, 2002).

Previous studies have empirically explored both the relationship between internationalisation and firm performance in the international business and the role of knowledge-based resources in explaining the performance differences of internationalising firms (for a review, see Contractor, 2007; Hitt et al., 2006). ${ }^{1}$ However, these studies examining the relationship between internationalisation and firm performance have been largely limited to advanced market multinational enterprises (MNEs), and in particular, the US and Japanese MNEs. Meanwhile, the international business environment has witnessed unprecedented changes associated with the arrival of new emerging market multinationals. These emerging market firms have accelerated their pace of internationalisation so as to quickly catch up earlier advanced market movers' competitive position. This opens up new avenues for improving both theoretical and empirical understanding of the performance impacts of internationalisation. However, there have been relatively few empirical studies conducted on internationalisation behaviours of these emerging market firms. This represents a notable research gap in internationalisation.

More importantly, these prior empirical studies on this research topic of internationalisation-performance relationship have offered inconclusive and even confusing evidence regarding not only the relationship between internationalisation and firm performance, but also the moderating effects of differential knowledge-based resources on the relationship between internationalisation and firm performance (Berry and Kaul, 2016; Kotabe et al., 2002; Lu and Beamish, 2004; Mishra and Gobeli, 1998). On the one hand, given the numerous studies examining the relationship between internationalisation and performance, have, in general, provided evidence of conflicting results (Capar and Kotabe, 2003; Hitt et al., 1997; Pangarkar, 2008), a few recent work has further reconciled theoretical arguments and confirmed an S-shaped relationship between internationalisation and firm performance and also a positive moderating role of intangible resources on such relationship. For example, Lu and Beamish (2004), perhaps the most widely cited studies in the literate on this line of research, report an S-curve relationship between internationalisation and firm performance for Japanese firms - with firm performance first decreasing, then increasing, then decreasing again as firms internationalisation, and they also argue and show that the relationship between internationalisation and firm performance is more positive, the higher the level of intangible assets (as measured by R\&D spending) the firm possesses. In contrast, other studies have found no evidence of an S-shaped relationship between internationalisation and firm performance, no do they find a positive moderation of this relationship by the firm's intangible resources. For example, using a longitudinal and comprehensive database on the population of US MNEs, Berry and Kaul (2016) find no evidence of either an S-shaped relationship between internationalisation and firm performance, or a 
significant moderating effect of intangible assets. This represents another important research gap in the literature and has seriously limited our understanding of the internationalisation strategy for firms in general and emerging market firms in particular.

Drawing upon the KBV, we argue that knowledge-based resources of emerging market firms play a more pivotal role in shaping the relationship between their internationalisation and performance. The KBV logic is insightful and pertinent in explaining our queries for two main reasons. First, international expansion demands more knowledge resources to buffer costs and risks incurred overseas due to continual liability of foreignness and market newness (Hymer, 1976; Zaheer, 1995). However, firms may face resource constrains when going international and, more importantly, the seriousness of this limitation hinges on the type of knowledge bases to be deployed abroad. Thus it is relevant and very important to assess what type of knowledge-based resources a firm possesses are more useful in helping it achieve more internationalisation premiums (i.e., internationalisation benefits) and experience less internationalisation discount (i.e., internationalisation costs) when expanding into foreign markets. Knowledge is particularly important for internationalising emerging market firms because conventional wisdom in strategy and international business research suggests that emerging market firms differ sharply from advanced market MNEs, which generally leverage and exploit their ownership-specific competitive advantages in foreign markets (Buckley and Casson, 1976; Dunning, 1993; Luo and Tung, 2007; Rugman, 1981). However, we should at this point acknowledge that emerging market firms have developed rapidly and many firms have already upgraded and developed their unique knowledge-based resources as well as a competitive advantage both through indirect inward internationalisation and direct outward international expansion activities. For example, a number of Chinese companies, such as Huawei, Lenovo, and Haier, have emerged to challenge conventionally dominant MNEs in the global competitive landscape by quickly developing unique knowledge-based resources and global competitive capabilities. Second, as an extension of the resource-based view, the KBV concerns a firm as a collection of knowledge resources (Kogut and Zander, 1993; Penrose, 1959; Wernerfelt, 1984), and specifically highlights the critical role of the firm's knowledge heterogeneity in determining its competitive position and performance (Barney, 1991). Accordingly, the fact that some emerging market firms are superior to others in the global marketplace can be, at least in part, ascribable to their possession of unique knowledge-based resources. Along this line of thinking, we believe that variations in performance of internationalising emerging firms emanate from differences in their knowledge-based resources.

Thus, our study is motivated by the aforementioned confusing jumble of findings and the urgent need to further clarify the relationship between internationalisation and firm performance research, and more importantly, the role of differential knowledge-based resources in moderating such relationship. More specifically, in this paper, we extend the above literatures by exploring whether and how emerging market firms can benefit from internationalisation and exploit knowledge resources for superior performance in the course of international expansion. In particular, we argue that, while the core idea behind the KBV is that the more knowledge a firm has, the better its performance, a more complex story, accounting for different types of knowledge-based resources, is more applicable and accurate. A firm's knowledge base can be characterised by the set of knowledge elements that it possesses. In this paper, we offer such a way by classifying a firm's knowledge-based resources into two types - technological knowledge and marketing knowledge, and then examine their respective effects on the relationship 
between internationalisation and performance of emerging market firms separately. Although certain type of knowledge-based resources may be more beneficial, others may be less or even detrimental.

The empirical analysis in this study is based on panel data for more than 100,000 manufacturing firms in China from 2001 to 2005. China is currently the largest emerging market in the world and is arguably the most active internationalising economy among the emerging markets (Child and Rodrigues, 2005; UNCTAD, 2010). Despite the increasing significance in the global competitive landscape of Chinese multinationals, our understanding of what drives the performance consequences of their internationalisation remains in its infancy and a puzzle. The surge of internationalisation by firms from China thus creates an urgent need to investigate the performance implications of their internationalisation strategies and the role of specific type of knowledge-based resources they possess in explaining the relationship between internationalisation and performance. Our study contributes to the understanding of the relationship between internationalisation and performance and the moderating role of specific types of knowledge-based resources on such relationship for firms in emerging economies in general and China in particular.

\section{Conceptual background and hypothesis development}

For decades, previous scholarship has emphasised the critical role of knowledge in creating strategic opportunities and theorising firm rents (Denrell et al., 2003; Simonin, 1999). The KBV of the firm has become one of the most widely accepted and influential theoretical perspectives in the strategic management and international business fields (Arend et al., 2014; Foss et al., 2013; Fransson et al., 2011; Kogut and Zander, 1993). As such, the KBV has become a dominant paradigm upon which arguments in academic journals and textbooks alike have been grounded. The KBV highlights that knowledge and competitive advantages as factors specific to a firm, rather than general to the external environment in which the firm operates. A fundamental tenet underlying KBV is firm knowledge heterogeneity. More specifically, the KBV presumes that firms within an industry are heterogeneous in the rare and valuable resources they possess, and such firm knowledge heterogeneity determines the variations in competitive advantages and explains performance differences. Reflecting on this point, research has generally suggested that "the heterogeneous knowledge bases and capabilities among firms are the main determinants of performance differences" [DeCarolis and Deeds, (1999), p.954]. Laying these presuppositions on the case of the international expansion, emerging market firms may exhibit a different level of internationalisation as well as performance outcomes of such strategy, thanks mainly to inherent idiosyncrasy in the knowledge they own. Furthermore, while the heterogeneous knowledge resources an emerging market multinational possesses can be transferred across markets within the boundary of the firm, different types of knowledge-based resources may allow emerging market firms to benefit differently in their process of international expansion.

Synthesising prior notions (Barney, 1991; Kogut and Zander, 1992), knowledge in this paper refers to particular know-how and skills (Miller and Shamsie, 1996). In this paper, we move a step further to divide knowledge resources into two common types, technological and marketing knowledge. Although it is widely accepted that knowledge 
can lead to enhanced firm capabilities and performance, most researchers have either ignored the differences between the two common types of knowledge or have chosen to address one or the other without clearly indicating the criteria when investigating their effects on the relationship between internationalisation and firm performance (e.g., Kotabe et al., 2002; Lu and Beamish, 2004). Our study draws upon the KBV literature to identify two types of knowledge-based resources and provides an important step forward by differentiating them and also empirically showing their differential moderating effects on the relationship between internationalisation and performance for emerging market firms. By differentiating between technological and marketing knowledge, we are able to advance our understanding of the role of different types of knowledge and the importance of $\mathrm{KBV}$ in explaining the performance variations among internationalising emerging market firms.

\subsection{Internationalisation and firm performance}

As previously noted, despite the excellent efforts by researchers to examine the relationship between internationalisation and performance, they have produced inconsistent or even conflicting results (Capar and Kotabe, 2003; Hitt et al., 2006). Thus, there remain theoretical and empirical gaps concerning this subject, and more importantly, empirical research has focused mainly on MNEs from advanced economies.

The increasingly complex, uncertain, and competitive business environment has made it difficult for firms to rely solely on their home markets, and thus, an increasing number of firms have been exploring global markets. However, internationalisation tends to be a 'two-edged sword' (Xiao et al., 2013). On the one hand, internationalisation can provide firms with some advantages, including opportunities for obtaining new resources and transferring core competencies to new markets for business growth (Buhner, 1987), integrating business activity across borders and allocating resources more efficiently and effectively, taking advantage of differences in factor markets (Chao and Kumar, 2010), and achieving economies of scale and scope as well as learning (Capar and Kotabe, 2003; Chao and Kumar, 2010; Ghoshal, 1987; Hamel, 1991; Kogut, 1985). On the other hand, internationalisation entails some unavoidable costs, including costs associated initial learning, cultural differences, and a lack of market experience (Hymer, 1976; Stinchcombe, 1965; Zaheer, 1995). Such costs can also arise from increased information asymmetry, and transaction/governance costs for multinationals (Gomes and Ramaswamy, 1999; Hitt et al., 1997; Lu and Beamish, 2004), and increased cultural/institutional diversity (Bartlett and Ghoshal, 1989).

Following these arguments, there has been a growing consensus among researchers that both the benefits and costs of internationalisation must be considered in any examination of the relationship between internationalisation and firm performance. In this line, a recent stream of research has theoretically enriched the internationalisation-performance literature by suggesting and empirically examining the possibility of curvilinearity (or two-stage specification) as against the underlying linearity-based premise in earlier studies in the relationship between internationalisation and performance. However, these recent studies focusing on advanced market MNEs have created more complex and inconsistent empirical findings on this relationship by suggesting and finding both U-shaped and inverted U-shaped relationships between internationalisation and performance (Geringer et al., 1989; Gomes and Ramaswamy, 1999; Hitt et al., 1997; Lu and Beamish, 2001). The U-shaped and inverted U-shaped 
models respectively represent two basic rationales on the nature of the internationalisation-performance relationship. The U-shaped hypothesis suggests that internationalising firms initially suffer a negative performance due to their lack of knowledge and experience of international market and insufficient scale economies and then benefit a positive performance as they acquire knowledge and experience and gain legitimacy in the target market (Qian, 1997; Ruigrok and Wagner, 2003). In comparison, the line of the inverted U-shape research argues for and finds that such internationalising firms initially generate positive returns and that their performance increases to the 'internationalisation threshold', a certain point at which increased governance and coordination costs exceed the benefits of continuous international expansion, causing their performance to level off beyond the optimal point (Geringer et al., 1989; Sullivan, 1994).

A closer examination of this literature, however, reveals some consistency within the seemingly contradictory findings. The conflicting results could be an outcome of incomplete theorisation about the full range of the benefits and costs of internationalisation. In this regard, the current scholarship has provided a more complete conceptualisation about the benefits and costs of internationalisation to explain the lack of consistent findings by developing a new S-shaped (or three-stage) framework for the relationship between internationalisation and performance (Contractor et al., 2003; Lu and Beamish, 2004). This multistage process of international expansion proposes that internationalising firms may cover a broader spectrum of internationalisation and thus it predicts a positive internationalisation-performance relationship for most of the internationalisation range which is both preceded (under-internationalisation) and succeeded (over-internationalisation) by domains of negative internationalisation-performance relationship. Using a sample of large firms, both Contractor et al. (2003) and Lu and Beamish (2004) have empirically confirmed the expectations of the S-shaped framework for the relationship between internationalisation and performance.

While the S-shaped hypothesis for the relationship between internationalisation and performance has come to be widely accepted and cited, the focus on large and early internationalising advanced market MNEs may raise some concerns regarding generalisability, especially to the latecomer emerging market firms which are increasingly undertaking intense internationalisation. Compared with their counterparts from advanced markets, emerging market firms tend to be relatively young, lack international experience, and their internationalisation efforts represent a relatively new phenomenon. We argue that studies using a sample of emerging market firms may be a useful extension of this stream research and can provide additional insights. Synthesising prior notions proposed by the multistage model of international expansion, our study attempts to extend this line of research into the context of emerging market firms. We therefore hypothesised:

Hypothesis 1 Internationalisation and firm performance have an S-shaped relationship for firms in China, with performance declining at low levels of internationalisation, increasing at moderate levels of internationalisation, and declining at high levels of internationalisation. 


\subsection{Firm knowledge-based resources}

Building on the KBV of the firm, we hypothesise an S-shaped relationship between internationalisation and performance as the baseline, and then investigate the moderating effects of a firm's different type of knowledge-based resources on this relationship. Knowledge has been recognised as a critical organisational resource (Dunning, 1993). Likewise, the KBV makes the point that firms are repositories of knowledge (Kogut and Zander, 1992; Spender, 1996) and the competitive advantages of firms arises from their superiority capability in creating and transferring knowledge. A fundamental tent of the $\mathrm{KBV}$ is that knowledge that is normally valuable, rare, difficult to imitate, and non-substitutable determines a sustainable competitive advantage (Barney, 1991; Peteraf, 1993). Therefore, knowledge resources vary in how rare and valuable they are and they also vary in the extent to which they can be transferred, imitated, or substituted (Barney, 1991; Tsoukas, 1996). The different types of knowledge-based resources may reflect a knowledge's differential ability to create and sustain a competitive advantage (Barney, 1991).

Applying knowledge-based resources is also at the heart of competitive advantage for MNEs (Buckley and Casson, 1976; Spender, 1996). The internationalisation of emerging market firms is particularly dependent upon innovatively combining their own firm-specific knowledge with that of incumbents because emerging market firms are knowledge constrained and emerging market firms typically suffer more from a number of liabilities of foreignness, newness, smallness and emergingness in the course of international expansion (Hymer, 1976; Xiao et al., 2013; Zaheer, 1995). Different types of knowledge-based resources may affect the potential to reap the benefits of internationalisation for emerging market firms when pursuing international expansion differently. However, empirical work has yet to identify the differential effects that these knowledge-based resources can have on the performance implications of internationalisation for emerging market firms. Drawing such a distinction between knowledge-based resources is important given that knowledge has multiple types. For a multinational firm, in particular, an emerging market firm, to avoid the institutional and market constraints it faces abroad, compete more effectively against global rivals, and take full advantage of internationalisation, it must transfer its rate and valuable knowledge in the global marketplace without making the knowledge simultaneously available to its rivals.

Knowledge can be characterised along different dimensions using various terms. To explore how the knowledge-based resources affect the performance consequences of an internationalisation strategy for emerging market firms, we draw upon the KBV literature to identify two types of knowledge resources and look at their differential influences on the performance outcomes of internationalisation for emerging market firms: technological knowledge and marketing knowledge. These two types of knowledge resources have been shown to have pronounced influences on firm operations and decisions (Kim and Hwang, 1992; Kotabe et al., 2002; Song et al., 2005). We meld the identification of the two common types of knowledge-based resources with the core ideas from the KBV about how knowledge resources vary in the extent to which they embody the resource attributes of value, rarity, inimitability, and non-substitutability (VRIN) (Barney, 1991).

Technological resources are those that used to develop and innovate new products or formulate innovative manufacturing processes (Fang et al., 2007; Tseng et al., 2007; 
Song et al., 2005). Technological knowledge, in particular, has long been the focus of many studies of firm-specific advantage (e.g., Cantwell, 1989; Porter, 1990; Rugman, 1981; Teece, 1977). Unlike marketing knowledge, technological knowledge can be replicated and shared throughout a firm's operations, which helps the firm compete successfully in multiple markets and provides a firm with advantages in its international expansion activities (Cantwell and Mudambi, 2005; Caves, 1996; Martin and Salomon, 2003), particularly when there is a greater variance in the levels of technological knowledge between the firm and its competitors within the industry. Consistent with this insights, there is empirical evidence that firms possessing more technological knowledge are particularly more likely both to tap foreign markets and to be successful in doing so (Caves, 1996; Dunning, 1993; Morck and Yeung, 1991). As a result, the international expansion is motivated by such technological advantage to exploit and make better use of the knowledge in multiple markets.

Meanwhile, such technological knowledge strength may also motivate firms to pursue international expansion with the desire to seek new technological knowledge resident in foreign markets, which can, in turn, be exploited in international markets to build their competitive advantages and achieve superior performance. This logic is particularly appropriate to apply to emerging market firms which normally experience late-mover disadvantages and suffer from technological weaknesses (Cuervo-Cazurra and Genc, 2008; Luo and Tung, 2007). It has been argued that emerging market firms use international expansion as a springboard to overcome their latecomer disadvantage and seek strategic assets from advanced markets and such strategic assets can be used by them to catch up their global rivals from advanced markets and upgrade their competitive advantages in international markets (Luo and Tung, 2007). Consistent with this insight, we further argue that seeking new external knowledge from international expansion can contribute to an emerging market firm's knowledge base. However, the firm is unable to assimilate and utilise such learning opportunities passively. Instead, as Cohen and Levinthal (1990, p.128) argue, a firm's absorptive capacity - referring to the firm's "ability to recognize the value of new information, assimilate it, and apply it to commercial ends" - determines the extent to which the firm can recognise and utilise external knowledge. Cohen and Levinthal (1990) further suggest that a firm's existing technological knowledge, such as R\&D investment, can improve its ability to internalise knowledge from external sources. Therefore, we propose that technological knowledge an emerging market firm possesses may not only determine its ability to reap internationalisation benefits by exploiting existing competitive advantages, but also enhance the potential to upgrade its competitive advantages by creating diverse knowledge-based resources that help the absorption of knowledge from a wide variety of external sources in the course of international expansion.

With this extended notation, we can argue that as emerging market firms do not possess equivalent levels of technological knowledge, firms with more technological knowledge, in general, put more effort into cultivating new ideas and innovating products, and innovating manufacturing processes (Kotabe et al., 2002; Tseng et al., 2007), which represent new potential sources of competitive advantages. Therefore, as technological knowledge "can have powerful effect on both cost and differentiation" [Porter, (1985), p.169], technology-intensive firms can benefit more from international competition by differentiating the products from their rivals or by lowering the production costs relative to their competitors in international markets (Kotabe et al., 
2002). Thus, we expect that the more a firm possesses technological knowledge, the more likely it benefits more and suffers less from international expansion. We therefore hypothesise:

Hypothesis 2 Ceteris paribus, a firm's technological knowledge moderates the relationship between internationalisation and firm performance such as firms with high levels of technological knowledge are more likely to increase the performance gains through internationalisation.

A similar logic also applies to firms with more marketing resources. Marketing resources are those used to analyse markets, build positive brand images, and differentiate products or services from competitors (Fang et al., 2007; Kotabe et al., 2002). Marketing knowledge, as usually reflected in advertising and promoting, can enable a firm to expand the sales and compete more effectively again global rivals by predicting changes in customer needs and preferences, and by creating durable relationships with customers (Song et al., 2005). Further, marketing knowledge is often used to build brands. Brands are rare, valuable, inimitable, and non-substitutable sources of competitive advantage because they are built in persistent and timely investments in marketing over time (Fang et al., 2007; Kor and Mahoney, 2005). More importantly, given the increasing globalisation of the world markets due to advances in modern communication and transportation technologies (Holt et al., 2004; Levitt, 1983), and the creation of a global consumer culture (Alden et al., 1999), firms that emphasise building a global brand by investing heavily on advertising and marketing activities are more likely to succeed in international markets. A firm's strong brand can lead to a sustainable competitive advantage (Capron and Hulland, 1999) and help the firm charge premium prices in international markets to enhance their performance as well (Kotabe et al., 2002).

In addition, the increased globalisation of markets and rapid emergence of global consumers not only enable a global brand to appear highly attractive in better fitting and targeting customers in international markets, but also help the firm achieve greater efficiency by developing standardised marketing programs across multiple markets (Levitt, 1983). In essence, we argue that, as another type of idiosyncratic resources, marketing knowledge can also provide competitive advantage (Barney, 1991; Wernerfelt, 1984) and may be valuable and difficult for competitors to imitate. Firms with high levels of marketing knowledge will achieve greater gains from international expansion than those with lower levels of marketing knowledge since such firms could simultaneously increase economic rents and reduce coordination costs by deploying their superior marketing knowledge in international markets. We therefore hypothesise that:

Hypothesis 3 Ceteris paribus, a firm's marketing knowledge moderates the relationship between internationalisation and firm performance such as firms with high levels of marketing knowledge are more likely to increase the performance gains through internationalisation.

However, unlike technological knowledge which, in general, are more explicit and more easily codified and transferred (Dhanaraj et al., 2004; Von Glinow and Teagarden, 1988), marketing knowledge is more tacit than product development and technology and thus may be relatively more immobile and difficult to be transferred (Lane et al., 2001; Shenkar and $\mathrm{Li}, 1999)$. While we have to acknowledge that it can be transferable, the transfer of marketing knowledge will be more difficult and time-consuming. Generally speaking, marketing knowledge is characterised by a high degree of tacitness and 
culture-specificity, such as consumer preference, and thus is far from being readily or easily transferred (Simonin, 1999). It has been further suggested that marketing knowledge is related more closely to procedural than to declarative knowledge (Kogut and Zander, 1993) by pointing out that "[w]hereas declarative knowledge refers to information or factual statements (i.e., knowing what something means), procedural knowledge refers to knowing how to do something" [Simonin, (1999), p.466].

In this study, we thus argue that the importance of knowledge-based resources in facilitating the implementation of a firm's internationalisation strategy will be largely determined by how valuable and how easily that knowledge can be transformed into competitive advantages in the process of international expansion. Since marketing skills or know-how are often deeply embedded in local market contexts, they are not as easily as technological knowledge codified in formulas or manuals. In this regard, prior research has also suggested that some firms have marketing-specific advantages that cannot easily be exploited abroad [Johansson, (1997), p.53]. For example, the withdrawing of both Carrefour and Walmart from South Korea has proved the fact that their marking knowledge and strength at home in France and the USA, respectively, where they have dominated both wholesale and retail level, may not be equally valuable and easily be duplicated in foreign market for predicting markets and analysing consumers' needs and preferences. Likewise, the Tesco's recent embarrassing retreat from the US market can also be, at least partially, attributed to the failure in transferring its marketing knowledge and know-how abroad.

In addition, even in the case where a firm can transfer its marketing knowledge and brand to international markets, heterogeneity in consumer markets and consumer knowledge across markets which are influenced by institutional, social, and cultural differences may diminish the value of the existing marketing knowledge (Fang et al., 2007). The consequence of this is that advertising and promoting-based marketing knowledge might be less valuable in the process of international expansion compared with the technological knowledge. Since the publication of Levitt's (1983) article on the globalisation of the market, developing more standardised marketing programs across foreign market becomes possible and has also been recognised as a successful strategy for a firm to benefit from economies of scale and building of a global brand. However, contrary to this view, it has been argued that no powerful empirical evidence exists to show the world market is converging and becoming homogeneous (Wind, 1986). Instead, due to the diversity in cultural and socioeconomic factor, and market structure, learning from local experience and learning by doing in each local market have become an essential approach for success in international markets. Marketing knowledge is still largely embedded in cultural understanding, and the ability to identify and fulfil customers' needs, desire, preference and behaviours in each local market determines whether a firm can succeed in that market. For example, as one of the most important marketing resources, the transfer of the brand value has been suggested to be challenging because of the time-consuming nature of brand building in new markets (Katsikeas et al., 2006). The difficulty in transferring the brand value often gives rise to the motivation to enter a new international market through the acquisition of a host market incumbent's marketing knowledge and brand assets (Capron and Hulland, 1999; Fang et al., 2007). For example, the Chinese PC marker, Lenovo has significantly expanded into international markets and become the largest $\mathrm{PC}$ brand in the world through its acquisition of IBM's PC business in 2005, including its established ThinkPad and 
ThinkCentre brand assets. Likewise, the difficulty of transferring its brand to South Korea also motivates Mahindra and Mahindra Limited (M\&M), an Indian automobile manufacturer, to acquire the marketing knowledge and brand assets of SsangYong whining entering Korean market.

Taken together, unlike technological knowledge which is generally embedded in more standardised procedures and can be more easily transferred across multiple markets in a formal and systematic language, marketing knowledge is more explicit and usually develops from the transfer of context-specific knowledge embedded typically in non-standardised and tailored process. Nevertheless, due its more socially and culturally complex nature, marketing knowledge is rather tacit and often ill-codified and thus cannot easily be transferred in the process of international market expansion compared with the technological knowledge. We therefore hypothesise that:

Hypothesis 4 Ceteris paribus, a firm's knowledge resources moderate the relationship between internationalisation and firm performance such as firms with technological knowledge are more likely to increase the performance gains through internationalisation than those with marketing knowledge

\section{Methodology}

\subsection{Data and sample}

The data for this study is drawn from the Annual Industrial Survey Database of the Chinese National Bureau of Statistics (NBS). This database contains the most comprehensive information on industrial firms in China (Tian, 2007). Every year, the NBS collects detailed data on each firm, and by law, all firms in China are required to cooperate with the survey and submit financial information (Chang and $\mathrm{Xu}, 2008$ ). The NBS collects key financial information as well as demographic information on all industrial firms in China with annual sales of at least renminbi 5 million (approximately USD 806,000 based on the official exchange rate in 2015), and publishes the aggregated firm-level information in the official China Statistics Yearbooks at the provincial and industry levels. NBS data are largely accurate and internally consistent for empirical analysis (Chow, 1993), and they have been used in strategic management and international business research (e.g., Chang and Xu, 2008; Tian, 2007). Consistent with previous studies (Gomes and Ramaswamy, 1999; Hitt et al., 1997; Ruigrok and Wagner, 2003; Thomas and Eden, 2004), the present study focuses on firms in China's manufacturing industry.

We obtained data for the period 2001 to 2005 to test the effect of internationalisation on firm performance and the moderating effects of differential knowledge resources on such relationship. The year 2001 is an appropriate starting point. Since China's entry into the World Trade Organization (WTO) at the end of 2001, Chinese firms faced increasing international competitive pressures, forcing them to accelerate their internationalisation process. Further, to minimise the institutional effect of the global financial crisis of 2007 to 2008 , we decide to end our sample in 2005. In addition, to neutralise the location effect on the internationalisation strategy and firm performance, we limited our sample to one of the most rapidly developing areas: The Yangtzi River Delta (YRD) region. This region, which covers Shanghai Municipality, Jiangsu and Zhejiang Provinces, is China's 
fastest-growing economic zone. Firms in the YRD region are rather homogenous, thus alleviating the concern that there is too much heterogeneity in our sample. Moreover, this region represents at least one-third of entire manufacturing firms in our dataset anyway, and it has become the largest major export base in China (for example, occupying over $40 \%$ of China's total exports in 2009). Following these procedures, we obtained a sample of more than 300,000 firm-year observations during 2001 to 2005.

\subsection{Variables and measures}

We use return on assets (ROA) as our measure of firm performance. Following previous studies (e.g., Chang et al., 2013), we also use operating return on assets (operating ROA) to address the concern that ROA may be sensitive to financial leverage or non-operating income. The operating ROA is defined as operating income divided by total assets. Because the results obtained using ROA are similar to those obtained using operating ROA, we report the results only for operating ROA.

In this study, internationalisation is defined as the extent of a firm's international operations and thus can capture the level of the firm's international involvement. Various measures have been used to capture the level of internationalisation, including the ratio of foreign sales to total sales (Capar and Kotabe, 2003; Geringer et al., 1989; Tallman and $\mathrm{Li}$, 1996), the ratio of foreign assets to total assets (Gomes and Ramaswamy, 1999; Sambharya, 1995), the ratio of foreign employees to total employees (Kim et al., 1989; Kohers, 1975), and the ratio of exports to total sales (Cadogan et al., 2009; Chiao et al., 2006; Geringer et al., 2000; Thomas, 2006). Many of these measures have substantial limitations in terms of capturing the extent of a firm's overseas expansion efforts. Moreover, some studies have criticised the use of a unidimensional measure of internationalisation and suggested the use of a multidimensional measure (e.g., Sullivan, 1994; Thomas and Eden, 2004). However, there has been little empirical support for the use of a multidimensional measure (e.g., Ramaswamy et al., 1996), and thus, some studies have argued for the use of a unidimensional measure of internationalisation.

Thus, there has been no agreement or standard approach for the measurement of internationalisation. Any measure of internationalisation should reflect the relative size and strategic importance of foreign and domestic operations (Grant, 1987). In the process of internationalisation, firms typically move through different stages, starting from exporting via agents and advancing to other forms of international involvement, including establishing a sales subsidiary and making foreign direct investment in production facilities (Johanson and Vahlne, 1977). For the sample period of 2001 to 2005, Chinese firms were still in the early stages of internationalisation, with exporting being the dominant mode of their foreign market participation (Aulakh et al., 2000; Child and Rodrigues, 2005). Even though outward foreign direct investment (OFDI from China has increased substantially in recent years, China's OFDI accounts for only a very small fraction of international expansion compared with that of its export. According to the NBS, averaging the amount between 2006 and 2010, the size of China's OFDI is no more than $4 \%$ of the export sales which achieved USD 1,578 billion in 2010 (Xiao et al., 2013). Exporting has been the most popular, quickest, and easiest way for Chinese firms to penetrate foreign markets and engage in internationalisation (Gao et al., 2010), and exporting was by far the most important aspect of China's international business activity during the sample period. Given the fact that Chinese firms have focused on global 
strategies characterised by high levels of export sales from their operations based in China, a measure of export intensity, not foreign sales by overseas subsidiaries, may be more relevant for Chinese firms. Therefore, consistent with previous studies (Cadogan et al., 2009; Chiao et al., 2006; Geringer et al., 2000; Thomas, 2006), we measure the level of internationalisation as the ratio of export sales to total sales (ESTS).

We measure technological knowledge and marketing knowledge using conventional measures, a firm's R\&D intensity and advertising intensity, respectively. R\&D intensity is a key component and widely used proxy for technological knowledge (Anand and Singh, 1997; Beamish and Delios, 1999; Stimpert and Duhaime, 1997; Zahra and George, 2002). We operationalise $R \& D$ intensity and advertising intensity as the ratio of $R \& D$ expenses to total sales (Davidson and McFetridge, 1985; Erramilli et al., 1997; Gatignon and Anderson, 1988), and the ratio of marketing-related expenses to total sales (Erramilli et al., 1997; Gatignon and Anderson, 1988; Vachani, 1995), respectively.

Following previous studies, we also incorporate the following control variables to predict firm performance: firm size, firm age, firm leverage, ownership structure, and industry, region, and year dummies. We measure firm size using the logarithm of total sales. Firm size is a variable which has been well-known to be related to firm performance (Contractor et al., 2003; Hitt et al., 1997; Lu and Beamish, 2004). We operationalise firm age as the number of years the firm has been in operation to control the effect of organisational life cycle on firm performance (Kim et al., 2010). We measure leverage as the ratio of total debt to total assets. The NBS database classifies firms in China into the following five types: state-owned enterprises (SOEs), collectives, reformed firms, private firms, and foreign-invested firms. State-owned and collective are conventional ownership structures, whereas private, reformed, and foreign-invested are modernised. Accordingly, we create three dummy variables: reformed firms, private firms, and foreign-invested firms, with conventional firms (i.e., SOEs and collectives) as a reference group. Finally, we control industry, region, and time effects using a set of two-digit industry dummies, two-digit region dummies and year dummies. To minimise the possible endogeneity problem and take into account the lag between internationalisation and performance gains, all time variant independent variables and control variables are included in the estimations with a lag of one year.

\section{Results}

This study uses firm-level panel data for hypothesis testing. In this regard, the ordinary least squares (OLS) method may not be appropriate in that unobserved firm-level heterogeneity may be correlated with independent variables, and thus, we use the generalised least squares (GLS) fixed-effects models to test the hypotheses (Wooldridge, 2002). ${ }^{2}$

Table 1 presents the means, standard deviations, and correlations among variables in the analyses. To further examine the severity of multicollinearity, we check variance inflation factors (VIFs) and the results show no serious problems of multicollinearity. Nevertheless, following Aiken and West's (1991) suggestion for analysing interaction effects, we mean-centre all variables used in creating the interaction terms to minimise the potential for multicollinearity and increase interpretability of interaction. 
Table 1 Descriptive statistics and correlation ${ }^{\mathrm{a}}$

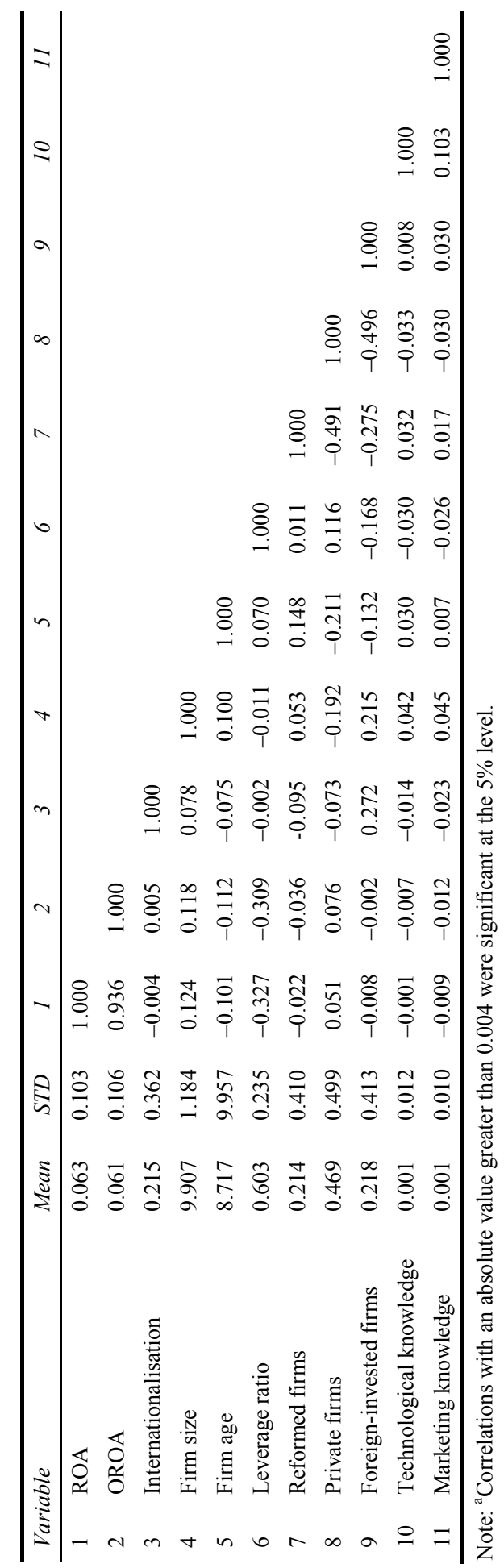


Table 2 Results of regression analysis ${ }^{\mathrm{a}, \mathrm{b}}$

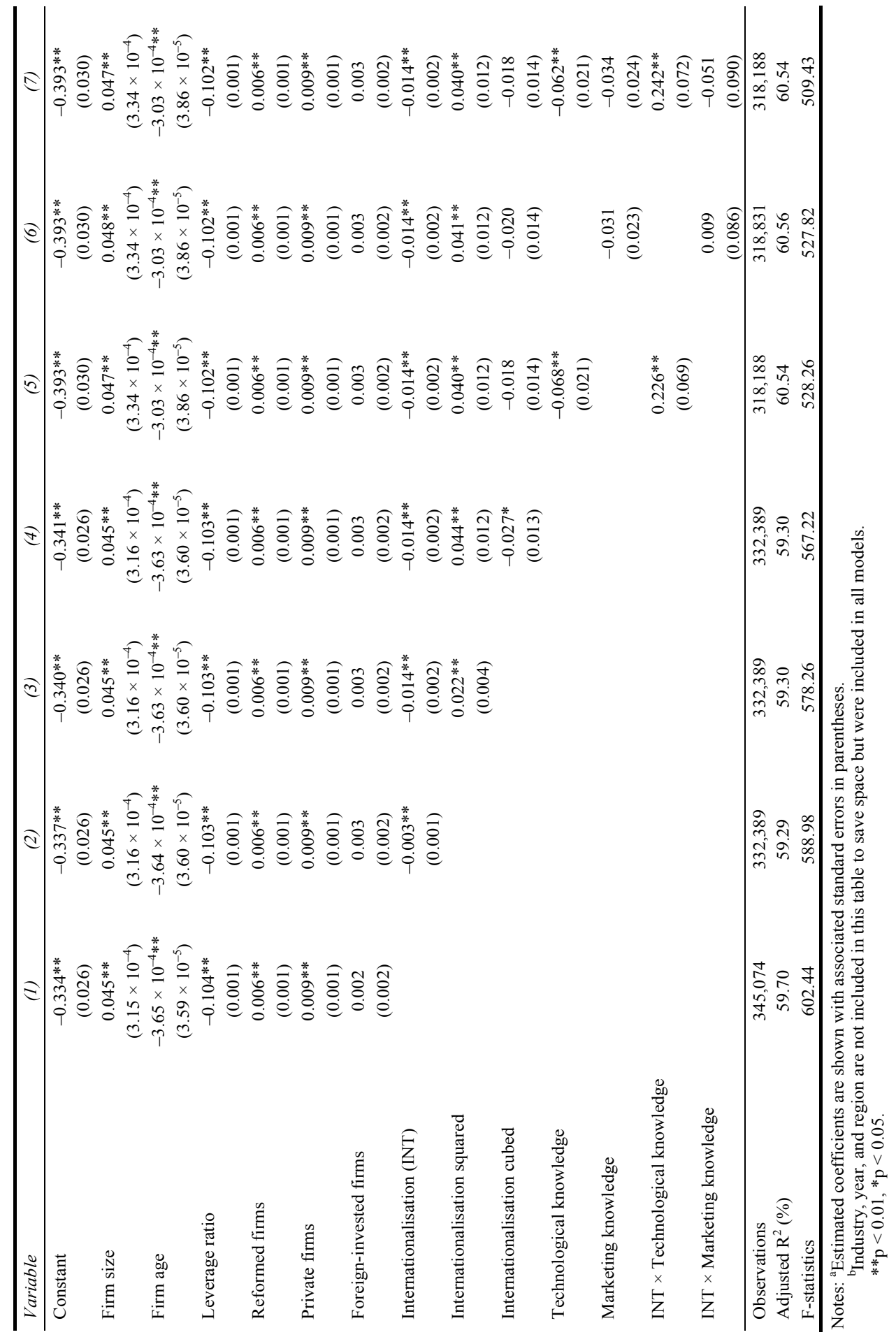


Table 2 shows the results of regression analyses. The general models for all runs in Table 2 are all supported, as indicated by the significant $F$-values and adjusted $R^{2}$. Model 1, which only includes the control variables, serves as the baseline model. We test Hypothesis 1 using models 2 to 4 , in which we built the test of the S-shaped relationship by adding the linear term of internationalisation in model 2 , its squared term in model 3 , and its cubic term in model 4 . As shown in model 4, a test of the joint significance of the linear, squared, and cubic terms of internationalisation provides strong support for Hypothesis 1 . That is, firm performance is negatively related to the liner term, positively related to the squared term, and negatively related to the cubic term, indicating an S-shaped multistage relationship between internationalisation and performance for firms from an emerging market of China.

Hypotheses 2 and 3 posit that the levels of technological and marketing knowledge will both have linear and positive moderating effects on the relationship between internationalisation and performance for emerging market firms, respectively. We test Hypotheses 2 and 3 by entering the interaction of internationalisation and technological knowledge and the interaction of internationalisation and advertising intensity in models 5 and 6, respectively. As shown in model 5 in Table 2, the moderating effect of technological knowledge is positively significant for firm performance. Therefore, we find supporting evidence for Hypothesis 2. However, as shown in model 6 in Table 2, we find that there is a negative but insignificant moderating effect of marketing knowledge on the relationship between internationalisation and firm performance. Therefore, Hypothesis 3 is not supported. Finally, we included all the interaction terms simultaneously for the full model in model 7 and the results show that both the main effects and the moderating effects remain qualitatively the same. Taken models 5 to 7 together, we find supporting evidence for Hypothesis 4, which posits a stronger positive moderating effect of technological knowledge than that of marketing knowledge on the relationship between internationalisation and firm performance.

\section{Discussion and conclusions}

The past three decades have witnessed a broad spectrum of emerging market firms which are actively implementing an internationalisation approach as a strategic alternative for organisational growth. Therefore, it is important to understand how firm performance of emerging market firms is influenced by their international expansion activities and what factors can explain the performance differentials of such international expansion activities among these firms. Yet, to date, there is still a paucity of literature on this prominent issue, and we know relatively little about whether should emerging market firms continue to expedite their international journey and what can moderate their performance outcomes of international expansion. The objective of this study is therefore to theorise and study the performance implications of internationalisation for firms from emerging markets and move a step further to assess the influences that internationalisation of emerging market firms may wield on the performance.

This research offers important contributions and insights to the strategic management and international business literature. We extend our knowledge of the performance outcomes of internationalisation by exploring the relationship that internationalisation had on firm performance for a sample of internationalising emerging market firms. While 
numerous prior studies have been conducted on the relationship between internationalisation and performance, the relationship between internationalisation and its performance outcomes remain complex. While some studies have adopted the opportunity perspective and emphasised a positive relationship between internationalisation and firm performance, others have focused on the liability of foreignness perspective and suggested a negative relationship. Although a more recent stream of research on this topic has focused on potential theoretical and methodological causes that might explain the lack of consisting findings in the literature, conflicting results still remain. In particular, our understanding of the internationalisation-performance relationship has been largely limited by the research focus on large MNEs from advanced markets. Although emerging market firms are increasingly diversifying into international markets, questions still remain about whether the existing theories and empirical results can generalise to firms expanding internationally from emerging market contexts. Reflecting the growing importance of emerging market firms in the global economy, we contribute to literature by addressing such concern of the generalisability by extending prior research into an important yet understudied emerging market context. This study uses China's internationalising firms as our empirical context and finds evidence for an S-shaped relationship between internationalisation and performance. Our finding of a S-shaped relationship between internationalisation and performance in a sample of large emerging market firms, which is consistent with Lu and Beamish's (2004) argument, support the coexistence of the opposing mechanisms of opportunity and risk encountered in the international expansion process. Moreover, prior studies have highlighted the importance role that knowledge resources in shaping the performance outcomes of internationalisation. We extend the $\mathrm{KBV}$ and examine the contingencies of differential knowledge resources to further disentangle the benefits of internationalisation from its costs for emerging market firms by arguing that, a more complex story, accounting for different types of knowledge-based resources, is more applicable and accurate. More specially, we divide knowledge resources into two different dimensions: technological knowledge and marketing knowledge, and explore their respective effect on the relationship between internationalisation and performance of emerging market firms separately. This approach allows us to distinguish the different types of knowledge resources in shaping the relationship between internationalisation and performance and enables us to unpack the complex mechanisms underlying the relationship between knowledge resources and performance of internationalising emerging market firms. The results, which reveal that the prominent differences in the moderation effect of different types of knowledge resources on the relationship between internationalisation and performance is also significant, provide strong support for our argument that knowledge should be separated out into different types to better understand which is more important for firms in the process of internationalisation. While a firm's knowledge profile has long been thought to play a key role in several strategic and international business issues as well as firm performance, the current research adds to the literature by extending the importance of knowledge-based resources to the topic of emerging market firms' internationalisation and specifically contributes to our understanding of how individual knowledge-based resources may stretch or contract a firm's ability to achieve a successful internationalisation.

While contributing to the theoretical development in this field, our findings also have important implications for managers. In all, empirical results suggest that when 
manufacturing firms from emerging markets, like China, decide to tap into international markets, they are likely to experience a performance downturn at low levels of internationalisation, increasing performance levels at moderate levels of internationalisation, and eventually another (final) performance downturn at high levels of internationalisation. Thus, managers of internationalising firms in emerging markets, like China, should not look to short-term performance when assessing an internationalisation strategy. Instead, they should be patient and confident enough to harvest the real benefits of internationalisation as they initially pursue international expansion and should also be aware of the danger of over-internationalisation. Nevertheless, mangers with the enough confidence and patience to stick through short-term instability in internationalisation may be rewarded by long-term gains ( $\mathrm{Lu}$ and Beamish, 2004).

In addition, the results of our study, in general, provide supporting evidence for the basic tenets of KBV. Yet, our arguments and empirical findings reveal that not all knowledge is equally important for emerging market firms when undertaking international expansion. Knowledge of varying types with differing characteristics along the KBV dimensions of VRIN differentially influences emerging market firms' performance in the process of international expansion. More specifically, our study highlights the importance for managers of emerging market firms to effectively utilise their knowledge-based resources, in particular, the technological knowledge in the process of international expansion. We find that the technological knowledge an emerging market firm possesses positively and significantly affects its performance implications when going international. Therefore, the importance of technological knowledge in increasing the likelihood of success for the international expansion should not be underestimated. One possible explanation for this finding is that technological knowledge is more valuable and more easily transferable for emerging market firms in their process of international expansion because such form of knowledge is more context independent than marketing knowledge. Technological knowledge does not need to be modified to fit local specific market conditions to the same extent as marketing knowledge and it therefore can support a rapid building of sustainable competitive advantage in foreign markets [Fang et al., (2007), p.1060].

However, our results suggest that, when expanding internationally, it might be difficult for emerging market firms to replicate their marketing resources across markets due to the significant institutional, cultural, and social heterogeneity between home and host market contexts. This heterogeneity will especially limit the successful international application of marketing resources, which, compared with the international deployment of technological resources, is more sensitive to local cultural and institutional factors, such as consumer tastes and preferences or distribution channel networks and members. The more complex and locally embedded a firm's marketing knowledge, the more difficult it will be to transfer effectively across markets. A highly differentiated marketing advantage, such as a strong brand which is usually embedded in the local context, may not contribute positively to the success in the course of an emerging market firm's international expansion. Therefore, when an emerging market firm is planning to expand into a foreign market which is institutionally or culturally much different from the home market, the firm should pay careful attention not only to designing appropriate product by exploiting its technological resources, but also to exercising additional care 
and emphasising differentiation by developing new locally embedded marketing knowledge in local market through heaving advertising and marketing activities.

This study is not without limitation. First, there has not been a uniform method for measuring internationalisation of firms in the literature. Our reliance on a single-item indicator, the percentage of export sales, is based on the nature of Chinese firms' internationalisation as well as driven by data availability from the NBS database. Studies that test our hypotheses using alternative measures of internationalisation may provide additional insights and further validation for the findings. Furthermore, our study relates to China. Our focus on a sample of firms from a single country, i.e., China, could raise concern about whether the findings can be generalised to firms from other emerging markets. We believe that these findings are applicable to other emerging market firms when these emerging market firms are in the early stages of international expansion and when some of them are still young. However, it would be useful for future research to employ firm data from other emerging market contexts to verify this reasoning empirically. Finally, as our sample only consists of relatively large manufacturing firms and does not incorporate manufacturing firms with annual sales of below renminbi 5 million as well as service firms, future studies using a sample of very small manufacturing firms or service firms from China may enhance the generalisability of our findings.

To conclude, this study explores the link between internationalisation and performance of emerging market firms and takes a further step to theorise about the potential knowledge-based moderators by distinguishing the effects of technological and marketing knowledge. We demonstrate that there is an S-shaped relationship between internationalisation and performance for emerging market firms, which suggests that emerging market firms may benefit more from the positive relationship between internationalisation and performance at both the early and late stages of the process of international expansion, but suffer more from the negative relationship between internationalisation and performance at the middle stage of this process. We further argue that not all knowledge is equally important for emerging market to succeed in international expansion. Our empirical results suggest technological knowledge have more positive influence than the marketing knowledge on the performance outcomes of internationalisation for emerging market firms. While the findings have enriched our understanding of both the relationship between internationalisation and performance of emerging market firms and the moderating effects of differential knowledge-based resources on this relationship, we also identify several promising niches for future research in the hope of moving this line of inquiry forward.

\section{Acknowledgements}

This work was supported by Hankuk Hankuk University of Foreign Studies Research Fund. 


\section{References}

Aiken, L.S. and West, S.G. (1991) Multiple Regression: Testing and Interpreting Interactions, Sage Publications, Newbury Park, CA.

Alden, D.L., Steenkamp, J-B.E.M. and Batra, R. (1999) 'Brand positioning through advertising in Asia, North America, and Europe: the role of global consumer culture', Journal of Marketing, Vol. 63, No. 1, pp.75-87.

Anand, J. and Singh H. (1997) 'Asset redeployment, acquisitions and corporate strategy in declining industries', Strategic Management Journal, Summer Special Issue, Vol. 18, No. S1, pp.99-118.

Arend, R., Patel, P. and Park, H. (2014) 'Explaining post-IPO venture performance through a knowledge-based view typology', Strategic Management Journal, Vol. 35, No. 3, pp.376-397.

Aulakh, P.S., Kotabe, M. and Teegen, H. (2000) 'Export strategies and performance of firms from emerging economies: evidence from Brazil, Chile, and Mexico', Academy of Management Journal, Vol. 43, No. 3, pp.342-361.

Barney, J.B. (1991) 'Firm resources and sustained competitive advantage', Journal of Management, Vol. 17, No. 1, pp.99-120.

Bartlett, C.A. and Ghoshal, S. (1989) Managing Across Borders: The Translational Solution, Harvard Business School Press, Boston.

Beamish, P.W. and Delios, A. (1999) 'Geographic scope, product diversification and the corporate performance of Japanese firms', Strategic Management Journal, Vol. 20, No. 8, pp.711-727.

Berry, H. and Kaul, A. (2016) 'Replicating the multinationality-performance relationship: is there an S-curve?', Strategic Management Journal, Vol. 37, No. 11, pp.2275-2290.

Buckley, P.J. and Casson, M. (1976) The Future of the Multinational Enterprise, Macmillan, London.

Buhner, R. (1987) 'Assessing international diversification of West German corporations', Strategic Management Journal, Vol. 8, No. 1, pp.25-37.

Cadogan, J.W., Kuivalainen, O. and Sundqvist, S. (2009) 'Export market-oriented behavior and export performance: quadratic and moderating effects under differing degree of market dynamism and internationalization', Journal of International Marketing, Vol. 17, No. 4, pp.71-89.

Cantwell, J. (1989) Technological Innovations in Multinational Corporations, Blackwell, Oxford.

Cantwell, J. and Mudambi, R. (2005) 'MNE competence-creating subsidiary mandates', Strategic Management Journal, Vol. 26, No. 12, pp.1109-1128.

Capar, N. and Kotabe, M. (2003) 'The relationship between international diversification and performance in service firm', Journal of International Business Studies, Vol. 34, No. 4, pp.345-355.

Capron, L. and Hulland, J. (1999) 'Redeployment of brands, sales-force and general marketing expertise following horizontal acquisitions: a resource based view', Journal of Marketing, Vol. 63, No. 2, pp.41-65.

Caves, R.E. (1996) Multinational Enterprise and Economic Analysis, Cambridge University Press, Cambridge.

Chang, S., Chung, J. and Moon, J.J. (2013) 'When do wholly owned subsidiaries perform better than joint ventures?', Strategic Management Journal, Vol. 34, No. 3, pp.317-337.

Chang, S.J. and $\mathrm{Xu}, \mathrm{D}$. (2008) 'Spillovers and competition among foreign and local firms in China', Strategic Management Journal, Vol. 29, No. 5, pp.495-518.

Chao, C.H. and Kumar, V. (2010) 'The impact of institutional distance on the international diversity performance relationship', Journal of World Business, Vol. 45, No. 1, pp.93-103. 
Chiao, Y.C., Yang, K.P. and Yu, C.M.J. (2006) 'Performance, internationalization, and firm-specific advantages of SMEs in a newly-industrialized economy', Small Business Economics, Vol. 26, No. 5, pp.475-492.

Child, J. and Rodrigues, S.B. (2005) 'The internationalization of Chinese firms: a case for theoretical extension?', Management and Organization Review, Vol. 1, No. 3, pp.381-410.

Chow, G.C. (1993) 'Capital formation and economic growth in China', Quarterly Journal of Economics, Vol. 108, No. 3, pp.809-842.

Cohen, W.M. and Levinthal, D.A. (1990) 'Absorptive capacity: a new perspective on learning and innovation', Administrative Science Quarterly, Vol. 35, No. 1, pp.128-152.

Contractor, F.J. (2007) 'Is international business good for companies? The evolutionary or multi-stage theory of internationalization vs. the transaction cost perspective', Management International Review, Vol. 47, No. 3, pp.453-475.

Contractor, F.J., Kundu, S.K. and Hsu, C.C. (2003) 'A three-stage theory of international expansion: the link between multinationality and performance in the service sector', Journal of International Business Studies, Vol. 34, No. 1, pp.5-19.

Cuervo-Cazurra, A. and Genc, M. (2008) 'Transforming disadvantages into advantages: developing-country MNEs in the least developed countries', Journal of International Business Studies, Vol. 39, No. 6, pp.957-979.

Davidson, W.H. and McFetridge, D.G. (1985) 'Key characteristics in the choice of international technology transfer mode', Journal of International Business Studies, Vol. 16, No. 2, pp.5-22.

DeCarolis, D.M. and Deeds, D. (1999) 'The impact of stocks and flows of organizational knowledge on firm performance: an empirical investigation of the biotechnology industry', Strategic Management Journal, Vol. 20, No. 10, pp.953-968.

Denrell, J., Fang, C. and Winter, S.G. (2003) 'The economics of strategic opportunity', Strategic Management Journal, Vol. 24, No. 10, pp.977-990.

Dhanaraj, C., Lyles, M.A., Steensma, H.K. and Tihanyi, L. (2004) 'Managing tacit and explicit knowledge transfer in IJVs: the role of relational embeddedness and the impact on performance', Journal of International Business Studies, Vol. 35, No. 5, pp.428-442.

Dunning, J.H. (1993) Multinational Enterprises and the Global Economy, Addison-Wesley, Wokingham, UK.

Erramilli, M.K., Agarwal, S. and Kim, S.S. (1997) 'Are firm specific advantages location-specific too?', Journal of International Business Studies, Vol. 28, No. 4, pp.735-757.

Fang, Y., Wade, M., Delios, A. and Beamish, P.W. (2007) 'International diversification, subsidiary performance, and the mobility of knowledge resources', Strategic Management Journal, Vol. 28, No. 10, pp.1053-1064.

Foss, N.J., Lyngsie, J. and Zahra, S.A. (2013) 'The role of external knowledge sources and organizational design in the process of opportunity exploitation', Strategic Management Journal, Vol. 34, No. 12, pp.1453-1471.

Fransson, A., Hakanson, L. and Liesch, P.W. (2011) 'The underdetermined knowledge-based theory of the MNC', Journal of International Business Studies, Vol. 42, No. 3, pp.427-435.

Gao, G.Y., Murray, J.Y., Kotabe, M. and Lu, J. (2010) 'A 'strategy tripod' perspective on export behaviors: evidence from firms based in an emerging economy', Journal of International Business Studies, Vol. 41, No. 6, pp.377-396.

Gatignon, H. and Anderson, E. (1988) 'The multinational corporations' degree of control over foreign subsidiaries: an empirical test of a transaction cost explanation', Journal of Law, Economics, and Organization, Vol. 4, No. 2, pp.305-336.

Geringer, J.M., Beamish, P.W. and DaCosta, R.C. (1989) 'Diversification strategy and internationalization: implications for MNE performance', Strategic Management Journal, Vol. 10, No. 2, pp.109-119.

Geringer, J.M., Tallman, S. and Olsen, D.M. (2000) 'Product and international diversification among Japanese multinational firms', Strategic Management Journal, Vol. 21, No. 1, pp.51-80. 
Ghoshal, S. (1987) 'Global strategy: an organizing framework', Strategic Management Journal, Vol. 8, No. 5, pp.425-440.

Gomes, L. and Ramaswamy, K. (1999) 'An empirical examination of the form of the relationship between multinationality and performance', Journal of International Business Studies, Vol. 30, No. 1, pp.173-188.

Grant, R.M. (1987) 'Multinationality and performance among British manufacturing companies', Journal of International Business Studies, Vol. 18, No. 3, pp.79-90.

Grant, R.M. (1996) 'Toward a knowledge-based theory of the firm', Strategic Management Journal, special issue, Vol. 17, No. S2, pp.109-122.

Hamel, G. (1991) 'Competition for competence and interpartner learning within international strategic alliance', Strategic Management Journal, special issue, Vol. 12, No. S1, pp.83-103.

Hitt, M.A., Bierman, L., Uhlenbruck, K. and Shimizu, K. (2006) 'The importance of resources in the internationalization of professional service firms: the good, the bad and the ugly', Academy of Management Journal, Vol. 49, No. 6, pp.1137-1157.

Hitt, M.A., Hoskisson, R.E. and Kim, H. (1997) 'International diversification: effects on innovation and firm performance in product-diversified firm', Academy of Management Journal, Vol. 40, No. 4, pp.767-798.

Holt, D.B., Quelch, J.A. and Taylor, E.L. (2004) 'How global brands compete', Harvard Business Review, Vol. 82, No. 9, pp.1-9.

Hymer, S. (1976) The International Operations of National Firms: A Study of Direct Investment, MIT Press, Cambridge, MA.

Johanson, J. and Vahlne, J. (1977) 'The internationalization process of the firm - a model of knowledge development and increasing foreign market commitments', Journal of International Business Studies, Vol. 8, No. 1, pp.23-32.

Johansson, J. (1997) Global Marketing: Foreign Entry, Local Marketing, and Global Management, Irwin, Chicago, IL.

Katsikeas, C.S., Samiee, S. and Theodosiou, M. (2006) 'Strategy fit and performance consequences of international marketing standardization', Strategic Management Journal, Vol. 27, No. 9, pp. $867-890$.

Kim, H., Kim, H. and Hoskisson, R.E. (2010) 'Does market-oriented institutional change in an emerging economy make business-group-affiliated multinationals perform better? An institution-based view', Journal of International Business Studies, Vol. 41, No. 7, pp.1141-1160.

Kim, W.C. and Hwang, P. (1992) 'Global strategy and multinationals' entry mode choice', Journal of International Business Studies, No. 23, No. 1, pp.29-54.

Kim, W.C., Hwang, P. and Burgers, W.P. (1989) 'Global diversification strategy and corporate performance', Strategic Management Journal, Vol. 10, No. 1, pp.45-57.

Kogut, B. (1985) 'Designing global strategies: comparative and competitive value added chains', Sloan Management Review, Vol. 26, No. 4, pp.15-28.

Kogut, B. and Zander, U. (1992) 'Knowledge of the firm, combinative capabilities, and the replication of technology', Organization Science, Vol. 3, No. 3, pp.383-397.

Kogut, B. and Zander, U. (1993) 'Knowledge of the firm and the evolutionary theory of the multinational corporation', Journal of International Business Studies, Vol. 24, No. 4, pp.625-645.

Kohers, T. (1975) 'The effect of multinational corporations on the cost of equity capital of U.S. corporation: an empirical study', Management International Review, Vol. 15, Nos. 2/3, pp.121-124.

Kor, Y.Y. and Mahoney, J.T. (2005) 'How dynamics, management, and governance of resource deployments influence firm-level performance', Strategic Management Journal, Vol. 26, No. 5, pp.489-496. 
Kotabe, M., Srinivasan, S.S. and Aulakh, P.S. (2002) 'Multinationality and firm performance: the moderating role of RandD and marketing capabilities', Journal of International Business Studies, Vol. 33, No. 1, pp.79-97.

Lane, P.J., Salk, J.E. and Lyles, M.A. (2001) 'Absorptive capacity, learning, and performance in international joint ventures', Strategic Management Journal, Vol. 22, No. 12, pp.1139-1161.

Levitt, T. (1983) 'The globalization of markets', Harvard Business Review, Vol. 61, No. 3, pp.92-102.

Lu, J.W. and Beamish, P.W. (2001) 'The internationalization and performance of SMEs', Strategic Management Journal, Vol. 22, Nos. 6-7, pp.565-586.

Lu, J.W. and Beamish, P.W. (2004) 'International diversification and firm performance: the S-curve hypothesis', Academy of Management Journal, Vol. 47, No. 4, pp.598-608.

Luo, Y. and Tung, R.L. (2007) 'International expansion of emerging market enterprises: a springboard perspective', Journal of International Business Studies, Vol. 38, No. 4, pp.481-498.

Martin, X. and Salomon, R. (2003) 'Knowledge transfer capacity and its implications for the theory of the multinational corporation', Journal of International Business Studies, Vol. 34, No. 4, pp.356-373.

Miller, D. and Shamsie, J. (1996) 'The resource-based view of the firm in two environments: the Hollywood film studios from 1936 to 1965', Academy of Management Journal, Vol. 39, No. 3, pp.519-543.

Mishra, C.S. and Gobeli, D.H. (1998) 'Managerial incentives, internalization, and market valuation of multinational firms', Journal of International Business Studies, Vol. 29, No. 3, pp.583-597.

Morck, R. and Yeung, B. (1991) 'Why investors value multinationality', Journal of Business, Vol. 64, No. 2, pp.165-187.

Pangarkar, N. (2008) 'Internationalization and performance of small- and medium-sized enterprises', Journal of World Business, Vol. 43, No. 4, pp.475-485.

Penrose, E. (1959) The Theory of the Growth of the Firm, Basil Blackwell, Oxford.

Peteraf, M.A. (1993) 'The cornerstones of competitive advantage: a resource-based view', Strategic Management Journal, Vol. 14, No. 3, pp.179-191.

Porter, M.E. (1985) Competitive Advantage, Free Press, New York.

Porter, M.E. (1990) The Competitiveness Advantage of Nations, Free Press, New York.

Qian, G. (1997) 'Assessing product-market diversification of U.S. firms', Management International Review, Vol. 37, No. 2, pp.127-150.

Ramaswamy, K., Kroeck, K.G. and Renforth, W. (1996) 'Measuring the degree of internationalization of a firm: a comment', Journal of International Business Studies, Vol. 27, No. 1, pp.167-177.

Rugman, A.M. (1981) Inside the Multinationals: The Economics of Internal Markets, Columbia University Press, New York.

Ruigrok, W. and Wagner, H. (2003) 'Internationalization and performance: an organizational learning perspective', Management International Review, Vol. 43, No. 1, pp.63-83.

Sambharya, R.B. (1995) 'The combined effect of international diversification and product diversification strategies on the performance of U.S.-based multinational corporations', Management International Review, Vol. 35, No. 3, pp.197-218.

Shenkar, O. and Li, J. (1999) 'Knowledge search in international cooperative ventures', Organization Science, Vol. 10, No. 2, pp.134-143.

Simonin, B. (1999) 'Transfer of marketing know-how in international strategic alliances: an empirical investigation of the role and antecedents of knowledge ambiguity', Journal of International Business Studies, Vol. 30, No. 3, pp.463-490.

Song, M., Droge, C., Hanvanich, S. and Calantone, R. (2005) 'Marketing and technology resource complementarity: an analysis of their interaction effect in two environmental contexts', Strategic Management Journal, Vol. 26, No. 3, pp.259-276. 
Spender, J.C. (1996) 'Making knowledge the basis of a dynamic theory of the firm', Strategic Management Journal, Vol. 17, No. S2, pp.45-62.

Stimpert, J.L. and Duhaime, I.M. (1997) 'Seeing the big picture: the influence of industry, diversification and business strategy on performance', Academy of Management Journal, Vol. 40, No. 3, pp.560-583.

Stinchcombe, A. (1965) 'Social structure and organizations', in March, J.G. (Ed.): Handbook of Organizations, pp.142-193, Rand McNally, Chicago.

Sullivan, D. (1994) 'Measuring the degree of internationalization of a firm', Journal of International Business Studies, Vol. 25, No. 1, pp.325-342.

Tallman, S. and Li, J. (1996) 'Effects of international diversity and product diversity on the performance of multinational firms', Academy of Management Journal, Vol. 39, No. 1, pp.179-196.

Teece, D.J. (1977) 'Technology transfer by multinational firms: the resource cost of transferring technological know-how', Economic Journal, Vol. 87, No. 346, pp.242-261.

Thomas, D.E. (2006) 'International diversification and firm performance in Mexican firms: a curvilinear relationship?', Journal of Business Research, Vol. 59, No. 4, pp.501-507.

Thomas, D.E. and Eden, L. (2004) 'What is the shape of the multinationality performance relationship?', Multinational Business Review, Vol. 12, No. 1, pp.89-110.

Tian, X. (2007) 'Accounting for sources of FDI technology spillovers: evidence from China', Journal of International Business Studies, Vol. 38, No. 1, pp.147-159.

Tseng, C.H., Tansuhaj, P., Hallagan, W. and McCullough, J. (2007) 'Effects of firm resources on growth in multinationality', Journal of International Business Studies, Vol. 38, No. 6, pp.961-974.

Tsoukas, H. (1996) 'The firm as a distributed knowledge system: a constructionist approach', Strategic Management Journal, Winter Special Issue, Vol. 17, No. S2, pp.11-25.

UNCTAD (2010) World Invest Report 2010: Investment in a Low-Carbon Economy, United Nations Publications, New York and Geneva.

Vachani, S. (1995) 'Enhancing the obsolescing bargain theory: a longitudinal study of foreign ownership of US and European multinationals', Journal of International Business Studies, Vol. 26, No. 1, pp.159-180.

Von Glinow, M.A. and Teagarden, M. (1988) 'The transfer of human resource management technology in Sino-US cooperative ventures: problems and solutions', Human Resource Management, Vol. 27, No. 2, pp.201-229.

Wernerfelt, B. (1984) 'A resource-based view of the firm', Strategic Management Journal, Vol. 5, No. 2, pp.171-180.

Wind, Y. (1986) 'The myth of globalization', Journal of Consumer Marketing, Vol. 3, No. 2, pp.23-26.

Wooldridge, J. (2002) Econometric Analysis of Cross Section and Panel Data, MIT Press, Cambridge, MA.

Xiao, S.F., Jeong, I., Moon, J.J., Chung, C.C. and Chung, J. (2013) 'Internationalization and performance of firms in China: Moderating effects of governance structure and the degree of centralized control', Journal of International Management, Vol. 19, No. 2, pp.118-137.

Zaheer, S. (1995) 'Overcoming the liability of foreignness', Academy of Management Journal, Vol. 38, No. 2, pp.341-363.

Zahra, S.A. and George, G. (2002) 'Absorptive capacity: a review, reconceptualization, and extension’, Academy of Management Review, Vol. 27, No. 2, pp.185-205. 


\section{Notes}

1 In this study, internationalisation refers to the extent of a firm's international operation and captures the international involvement of the firm. The terms, such as international diversification, internationalisation, international expansion, multinationality, geographic diversification, and international diversify, are often used interchangeably in the literature to refer to the same strategic management construct (Capar and Kotabe, 2003).

2 We also ran random-effects models as a robustness check. Results for the random-effects models were generally consistent with the fixed-effects results. Detailed information on random-effects models is available upon request. 